\title{
소아에서 발생한 Inflammatory Myofibroblastic Tumor in the Larynx
}

부산대학교 의학전문대학원 이비인후과학교실

김재욱 · 김민식 · 이유미 · 이진춘

\section{Inflammatory Myofibroblastic Tumor in the Larynx of a Child : A Case Report}

\author{
Jae-Wook Kim, MD, Minsic Kim, MD, Yumi Lee, MD and Jin-Choon Lee, MD, PhD \\ Department of Otorhinolaryngology-Head and Neck Surgery, Pusan National University School of Medicine, \\ Busan, Korea
}

\begin{abstract}
- ABSTRACT -
Inflammatory myofiber tumor (IMT) is a rare borderline tumor with uncertain behavior. This tumor is also known as inflammatory tumor, hematocyte granuloma, and sometimes referred to as inflammatory fibrosarcoma. IMT is a rare tumor of mesenchymal origin and is most commonly found in the lungs of children and adolescents. It is known that it may occur mainly in the mesentery and retina, but not in the head and neck region. Herein, we report a rare case of inflammatory myofibroblastic cells in the larynx in a 9 year-old child. (J Clinical Otolaryngol 2017;28:302-306)
\end{abstract}

KEY WORDS : Larynx $\cdot$ Child $\cdot$ Inflammatory myofibroblastic tumor.

\author{
서 론 \\ 염증성 근섬유모세포종양(IMT)은 불확실한 행동을 \\ 보이는 드문 경계성 종양이다. 이 종양은 염증성 가종양, \\ 혈질세포육아종으로도 알려져 있으며 염증성 섬유육종 \\ 으로 불리는 경우도 있다. ${ }^{1)}$ 염증성 근섬유모세포종 \\ (IMT)은 중간엽 기원의 드문 종양으로, 어린이와 청소 \\ 논문접수일 : 2017년 9월 20일 \\ 논문수정일 : 2017년 10월 18일 \\ 심사완료일 : 2017년 11월 10일 \\ 교신저자 : 이진춘, 50612 경남 양산시 물급읍 금오로 20 \\ 부산대학교 의학전문대학원 양산부산대학교병원 이비인후 \\ 과학교실 \\ 전화 : (055) 360-2652·전송 : (055) 360-2126 \\ E-mail:ljc0209@hanmail.net
}

년의 폐에서 가장 많이 발견된다. ${ }^{2}$ 증상이 있는 폐색을 일으키는 상부기도의 침범은 매우 드물게 발생하며, 일 반적으로 호흡, 천명음 및 운동시 호흡 곤란과 같은 천 식으로 오인 될 수 있는 증상이 있다. ${ }^{3)}$ 폐 이외에도 장간 막 및 망막에서 주로 발생할 수 있으나, 두경부 영역에서 는 잘 발생하지 않는다고 알려져 있다. 저자들은 애성을 주소로 내원한 9세 남아 환자의 후두부에 발생한 염증 성 근섬유모세포증 1 예를 제시하고 염증성 근섬유모세 포증 임상 병리학, 조직 병리학 및 치료에 대한 논의를 하고자 한다.

\section{증 례}

2010년 6월 4일 9세 남자가 7개월 간의 애성을 주소로 양산부산대학교병원 이비인후과 외래에 내원하였다. 


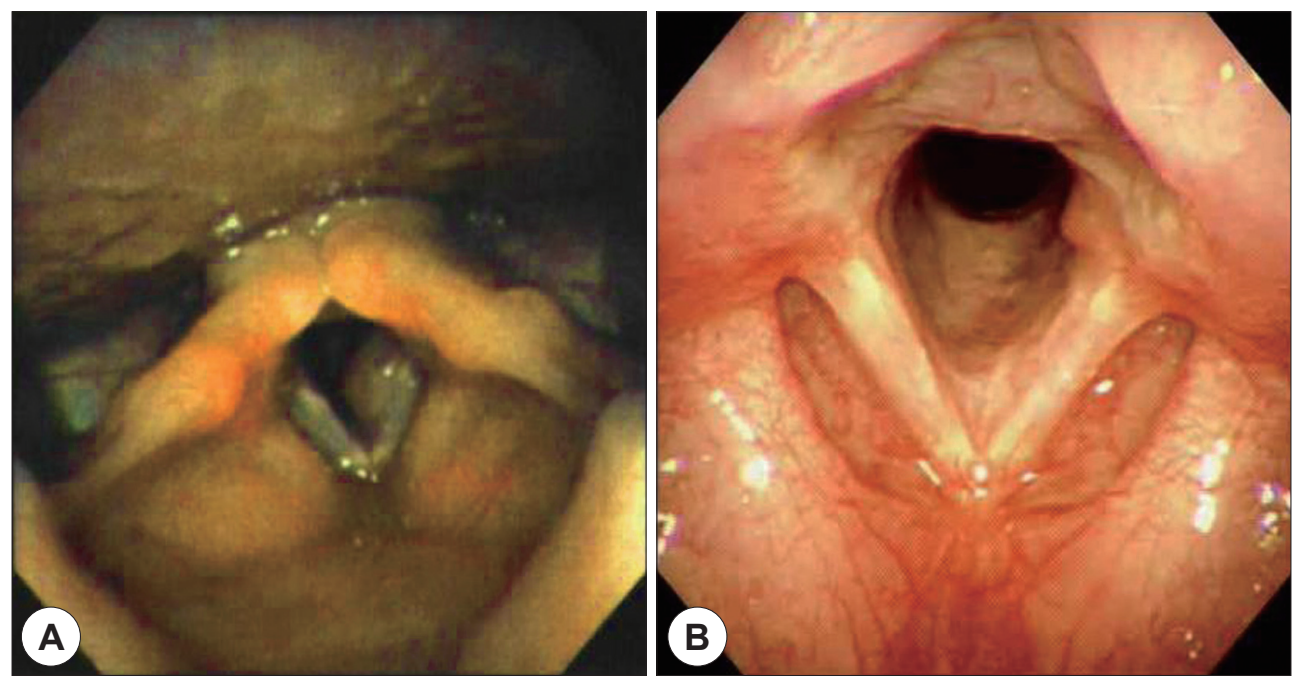

Fig. 1. A : Flexible laryngoscopic findings before surgery : $1.0 \mathrm{~cm}$ sized mass on left subglottic lesion. B : Flexible laryngoscopic after 5 years of operation : no recuurance.
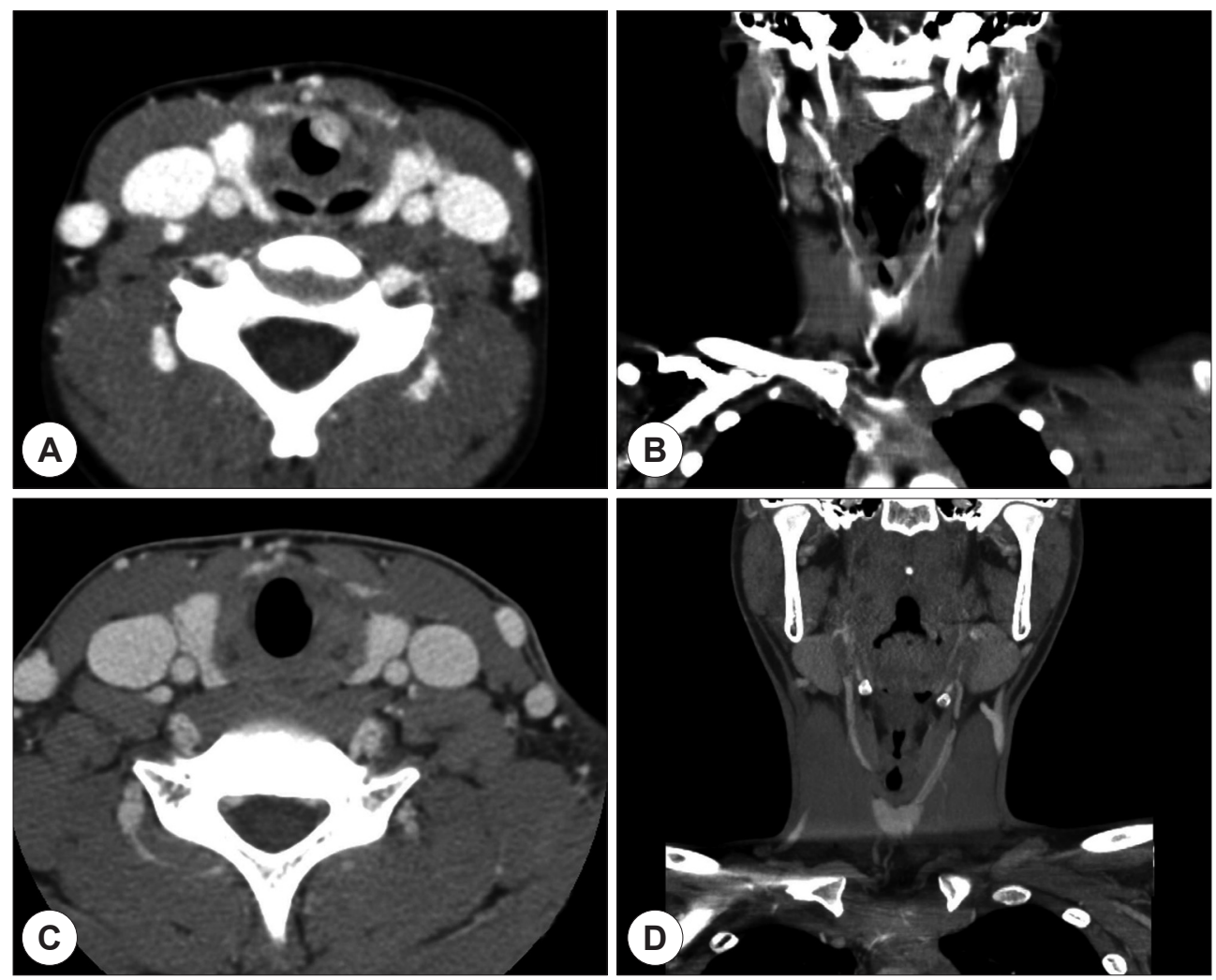

Fig. 2. A, B : Preoperative larynx computed tomographic (CT) images. Axial (A) and coronal (B) CT images show 9 $\mathrm{mm}$ sized mass in the larynx with increased contrast. C, D : Postoperative larynx computed tomographic (CT) images. Axial (C) and coronal (D) CT images show no recurrence. 
과거력상 특이 소견이 없었으며 발열 등의 특이한 전신 증상도 없었다. 외래에서 시행한 연성 후두경 검사상 좌측 성문하부에 $1.0 \mathrm{~cm}$ 크기의 낭종성 종물이 관찰되 었고 성대의 운동성은 정상이었다(Fig. 1A). 환아 나이 를 고려하여 1달간의 Acetylcysteine Cap $200 \mathrm{mg}$ 약물 치료 후 애성이 호전되어 1달간 추가 약물 치료를 시행 후 애성 증상은 호전되었으나 후두경소견상 낭종성 종 물의 변화는 없었다. 6 개월의 추적관찰 후 후두컴퓨터 단층촬영을 시행하여 성문하부에 조영이 증가된 $9 \mathrm{~mm}$ 크기의 용종성 종물 소견을 확인하였고(Fig. 2A, B), 수 술적 제거를 위해 2011년 2월 7일 기도삽관을 통한 전 신마취후, 현미경하 후두미세수술을 시행하였다. 수술 소견상 $0.8 \times 0.8 \mathrm{~cm}$ 크기의 단단하고 둥근 모양의 약간 의 유경성(peduncu-lated)이 있는 종물이 전교련 직후 방에서 좌측 성대에 강하게 부착되어 있었다. 종물은 성대의 근육층은 침범되지 않은 상태로, 성대인대 손상 없이 레이져를 이용하여 제거할 수 있었다. 수술 후 병 리학적 검사에서는 증식된 방추형 세포와 세포질이 풍 부한 유상피세포 모양의 근섬유모세포들이 섬유상 다 발을 이루고 있으며, 세포들 사이로 형질세포와 림프구 가 침윤되어 있는 소견이 관찰되었다(Fig. 3A). 세포질 이 풍부한 유상피세포 모양의 근섬유모세포들은 현저한 핵소체를 가지고 있었고(Fig. $3 \mathrm{~B}$ ), 종양세포들은 anaplastic lymphoma kinase (ALK) 단백질 면역조직화학 염색에서 양성을 나타냈다(Fig. 3 C). 이러한 조직검사 결과 염증성 근섬유모세포종으로 진단되었다. 수술 후 5 년간 외래를 통해 경과관찰 중이며, 외래에서 시행한 연성 후두경 검사(Fig. 1B) 및 2015년 2월 16일 시행한 후두컴퓨터단층촬영상 $(F i g .2 \mathrm{C}, \mathrm{D})$ 국소재발 소견없는 것을 확인하였다.

\section{고 찰}

염증성 근섬유모세포종양(IMT)은 중간엽 기원의 드 문 종양으로, 전신의 어느 부위에서도 발생할 수 있고, 특히 어린이와 청소년의 폐에서 가장 많이 발견된다. ${ }^{2)}$ 두경부에서는 부비동이 가장 흔히 발생하는부위이며 편도와 치아주위, 인두주위강 등에도 발생하기도 한다. 그러나 후두에서 발생하는 염증성 근섬유 모세포성 종양
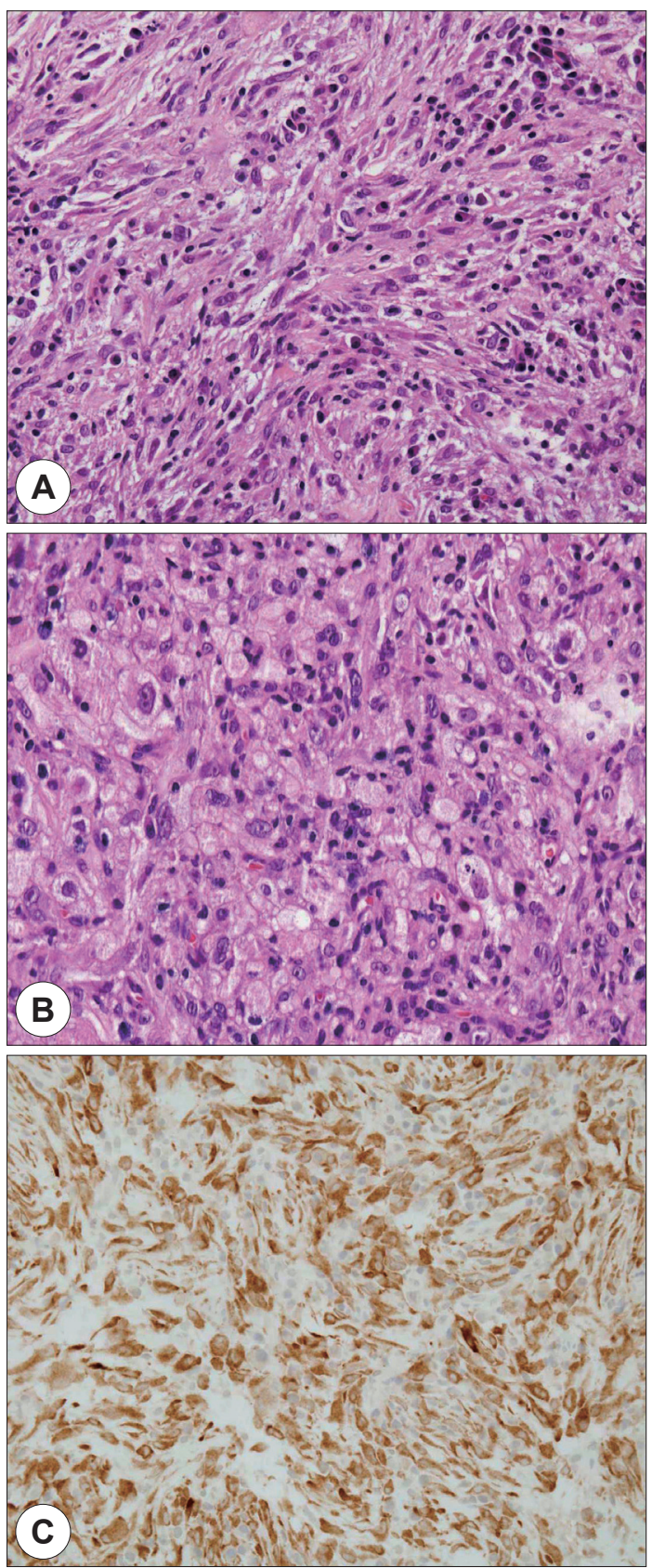

Fig. 3. Pathologic findings. A : There were proliferating spindle cells and cytoplasm-rich oocyte-like fibroblasts form fibrous bundles. Plasma cell and lymphocyte infiltration was observed between myofibroblasts. B : The cytoplasm-rich fibrous cell-like myoblasts had remarkable nucleoli. C : Tumor cells were positive for anaplastic lymphoma kinase (ALK) protein immunohistochemical staining. 
은 매우 드물고, ${ }^{4)}$ 재발의 가능성이 있으나 치료 방법이 확실하게 정립되어 있지 않다. ${ }^{5}$

염증성 근섬유모세포종양은 양성 임상 경과를 보이 며, ${ }^{6}$ 동반 증상은 비특이적이며 발생한 후부부위에 의한 국소적인 증상을 유발할 수 있다. 그 외에 체중감소, 불 명열, 저색소 및 소적혈구빈혈, 혈소판증가증, 고감마글 로불린혈증, 높은 적혈구침강속도와 같은 전신증 상 및 징후를 나타내는 경우도 있다. ${ }^{7)}$ 하지만 대부분 후두에 발생한 염증성 근섬유모세포종은, 전신증상이 동반되 지 않는다고 알려져 있다. ${ }^{8}$ 본 증례에서도 환아는 전신 증상 및 징후는 없었고, 쉰목소리가 유일한 증상이었다.

진단은 다른 질환을 배제한 후에 내릴 수 있으며 전산 화단층촬영이나 자기공명영상촬영은 진단적 가치보다 는 종양의 침범범위 및 치료계획을 결정하는 데 도움을 줄 수 있으며 조직생검을 통해서만 진단이 가능하다. ${ }^{9,10}$ 본 증례에서도 수술을 통한 조직검사를 통해 진단이 가 능하였으며, 수술전 전산화단층촬영을 통해 종양의 침 범범위를 확인하였고, 수술 후 전산화단층촬영을 통해 재발하지 않은 소견만을 확인할 수 있었다.

염증성 근섬유모세포종의 병태생리는 명확하게 밝혀 지진 않았다. 대게 이러한 병변은 엡스타인-바 바이러스 (Epstein-Barr virus), 인간 헤르페스 바이러스 8(Human herpes virus 8), 외상, 수술 또는 이물질에 의한 과도한 면역 반응과 같은 양상 반응 과정으로 간주되었다."

병리학적으로, 염증성 근섬유모세포종은 형질세포, 림프구및 호산구의 염증성 침윤을 동반한 근섬유모세 포 및 방추형 섬유모세포의 증식으로 이루어진 신생물 로 정의된다. ${ }^{11)}$ Coffin 등은 세가지 병리학적인 특징을 다음과 같이 제시하였다. 1) 점액성, 혈관성, 그리고 결절 성 근막염과 유사한 염증부위 ; 2) 섬유조직구종과 유 사한 염증 세포가 섞인 소형 방추형 세포 ; 그리고 3) 섬유질의 반흔과 유사한 조밀한 판형 콜라겐. ${ }^{12)}$ 병리학 적 소견상 방추형 세포의 밀도가 높고 다발성 일수록 재 발률이 높다. ${ }^{7}$ 2001년 Coffin 등은 염증성 근섬유모세포 종의 $1 / 3$ 에서 ALK 양성 반응을 보이고, ${ }^{13)}$ 염색체 $2 \mathrm{p} 23$ 부위의 클론 재배열에 의해 ALK가 발현된다고 보고하 였다. ${ }^{14)}$

$\mathrm{ALK}$ 의 발현은 염증성 근섬유모세포종 진단의 강력한 양성 예측 인자이다. 본 증례에서도 진단을 위한 병리학
적 검사에서 방추형 세포의 증식을 확인하였고, 기질에서 는 림프 구와 형질세포의 침윤이 관찰되었다. 드물게 비 정형 세포가 보였으나 육종에서 보이는 비정형 세포와 는 다르게 비특이적이었다. 또한 면역조직화학적검사 에서는 ALK-1에 양성반응을 보여, S-100 단백과 CD34 및 cytokeratin에서는 음성반응을 보여 염증성 근섬유모 세포종으로 진단 할 수 있었다.

염증성 근섬유 모세포성 종양의 치료원칙은 아직까지 정립되어있지 않지만 레이져를 이용한 내시경적 절제 술을 많이 시행하고 고용량 스테로이드 치료를 동반할 수 있다. 반복적으로 재발하는 다발성의 염증성 근섬유 모세포성 종양의 경우 반후두절제술을 고려해볼 수도 있다. ${ }^{1,15)}$ 스테로이드 투여는 염증성 근섬유 모세포성 종 양의 치료에 효과가 있다고 생각되지만 수술 전에 투여 시 즉각적인 반응은 기대 할 수 없고, 항암요법 및 방사 선요법은 수술 후 종양이 완전절제가 되지 않아 재발 및 전이가 있을 때 고려된다. ${ }^{9} \mathrm{Ma}$ 등은 소아의 염증성 근섬유 모세포성 종양 치료는 수술과 스테로이드를 동 시에 사용하는 것이 좋다고 보고한 바가 있다. ${ }^{9,16)}$ 본 증 례에서는 $\mathrm{CO} 2$ 레이져를 이용한 현미경하 후두미세수 술만을 시행하였고, 스테로이드는 사용하지 않았으나 수술 결과는 성공적이었다.

발생 빈도가 많지 않아 안정성에 대한 예후는 확립되 어 있지 않지만, 발생위치에 따라 다소 차이가 있으며 재 발 및 사망한 예에서는 대부분 종물의 크기가 커서 주위 조직으로의 침범이 심한 경우나 완전절제가 힘든 위치 에 발생한 경우이다. 수술로 완전 제거되었다고 하더라 도 국소전이나 재발의 가능성이 있어, 정기적으로 경과 관찰하면서 재발여부를 확인하여야 한다.

염증성 근섬유모세포종은 발생빈도의 희소성으로 인 해 진단, 치료 및 예후에 대해서 아직 논란의 여지가 많 으나 본 증례와 같이 후두 성대에서 발생한 비교적 작은 염증성 근섬유모세포종의 경우에는 $\mathrm{CO} 2$ 레이져를 이용 한 현미경하 후두미세수술을 통해 제거할 수 있음을 알 수 있었다.

\section{결 론}

우리는 성대 낭종으로 오인된 염증성 근섬유모세포종 
을 가진 9세 남아의 증례를 보고한다. 레이져를 동반한 후두미세수술을 시행함으로서 재발소견 없이 완전 절제 가능하였음을 이번 증례를 통해 확인할 수 있었다. 성대 손상을 예방하면서, 병인을 남기지 않고 완전히 절제하는 것이 국소 재발을 방지하는데 중요할 것으로 사료된다.

중심 단어 : 후두 · 소아 · 염증성 근섬유모세표 종양.

\section{REFERENCES}

1) Do BA, Varshney R, Zawawi F, Levental M, Caglar D, Young J. Inflammatory myofibroblastic tumor of the larynx-a case report. J Voice 2014;28:258-61.

2) Qian Yan X-LH. Inflammatory myofibroblastic tumor of the larynx: report of a case and review of the literature. Int $J$ Clin Exp Pathol 2015;8.

3) Kieu MQ, Thottam PJ, DaCosta V, Gonzalez-Krellwitz L, Poulik JM, Madgy DN. Treatment of inflammatory myofibroblastic tumor of the subglottis with KTP laser: a case report. J Voice 2014;28:841 el-4.

4) Kendall CH, Johnston MN. Pseudo-malignant laryngeal nodule (inflammatory myofibroblastic tumour). Histopathology 1998;32:286-7.

5) Lee SM, Goh JY, Wang SG, LEE YS, Laryngeal Pseudotumor Arising in the Paraglottic Space. J Clinical Otolaryngol 2012;23:300-3.

6) Izadi F, Ghanbari H, Azizi MR, Gasembaglou S, Manteghi MJ, Ghanbari A. Inflammatory myofibroblastic tumor of the larynx: a case report. Iranian Journal of Otorhinolaryngology 2016;28:79-82.

7) Batsakis JG, Luna MA, El-Naggar AK, Goepfert H. "Inflammatory Pseudotumor": What is it? How Does it Be- have? Annals of Otology, Rhinology \& Laryngology 1995; 104:329-31.

8) Munoz A VM. Inflammatory pseudotumor of the larynx: MR findings in a child. Pediatr Radiol 2001;31:459-60.

9) Mergan F, Jaubert F, Sauvat F, Hartmann O, Lortat-Jacob $\mathrm{S}$, Révillon Y, et al. Inflammatory myofibroblastic tumor in children: clinical review with anaplastic lymphoma $\mathrm{ki}$ nase, Epstein-Barr virus, and human herpesvirus 8 detection analysis. Journal of Pediatric Surgery 2005;40:1581-6.

10) Ma L, Wang K, Liu WK, Zhang YK. Is radical surgery necessary to head and neck inflammatory myofibroblastic tumor (IMT) in children? Child's Nervous System 2009;25: 285-91.

11) FLETCHER VYJACDM. WHO classification of soft tissue tumours (4th) edition. Pathology 2013;46(2):95-104.

12) Coffin CM, Watterson J, Priest JR, Dehner LP. Extrapulmonary Inflammatory Myofibroblastic Tumor (Inflammatory Pseudotumor): a clinicopathologic and immunohistochemical study of 84 cases. Am J Surg Pathol 1995;19:85972.

13) Coffin CM, Patel A, Perkins S, Elenitoba-Johnson KSJ, Perlman E, Griffin CA. ALK1 and p80 Expression and Chromosomal Rearrangements Involving $2 p 23$ in Inflammatory Myofibroblastic Tumor. Mod Pathol 2001;14:56976.

14) Gleason BC, Hornick JL. Inflammatory myofibroblastic tumours: where are we now? Journal of Clinical Pathology 2008;61:428-37.

15) Suh SI, Seol HY, Lee JH, Lee YH, Kim TK, Lee NJ, et al. Inflammatory myofibroblastic tumor of the larynx. Head \& Neck 2006;28:369-72.

16) Lee DK, Park HS, Rha SH, Ahn JK. Low grade myofibroblastic sarcoma in postauricular area: a case report. $J$ Clinical Otolaryngol 2010;21:253-6. 